\title{
Reflection on pastoral care in Africa: Towards discerning emerging pragmatic pastoral ministerial responses
}

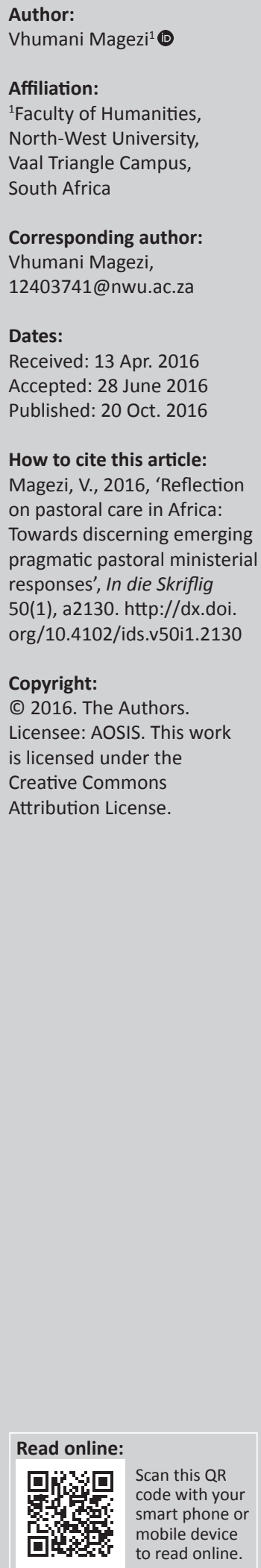

Pastoral care takes different forms in responding to people's needs in their context. Accordingly, over the centuries it has evolved in response to emerging needs. Historical developments in pastoral care are well-documented. However, pastoral care in Africa has a short and unsystematically documented history. Scholarly discussions on pastoral care concerning the continent tend to be considered under African theological frameworks. Notwithstanding the already existing weaknesses in African theological discussion, pastoral care in Africa has remained fragmented with diverse and seemingly knee-jerk approaches in guiding individuals who provide pastoral care. In view of this, this article firstly aims to provide a broad overview and initiate a discussion on the current challenges in pastoral care in Africa. Secondly, it aims to reveal some gaps worth pursuing by scholars in the discipline. Thirdly, it sheds some light on approaches employed by pastoral practitioners in pastoral ministry practice. In doing so, this article opens the lid on some perspectives adopted in ministry work on the frontlines, that is, providing pastoral care to people in their communities - particularly church communities. This article first outlines the problem to be addressed followed by an overview of pastoral care in Africa. It then proceeds to address potential research opportunities within the discipline. Finally, it highlights some emerging approaches in providing pastoral care in the communities. This article does not focus on one particular pastoral care issue, but gives an overview of the situation relative to pastoral care in Africa and the emerging responses.

\section{Problem statement: Pastoral care and the African situation}

Pastoral care is an internationally established field despite the divergent views on the meaning of the word pastoral. Patton (2013:99-103) noted in his writing within the context of the International Pastoral care and Counselling Movement that the word pastoral means different things. He asks whether pastoral refers to caring attitudes and acts, or if it refers to administrative oversight by a responsible clergyperson. A response to this question depends on one's confessional tradition. It could mean one or the other or both. However, what can be derived from this is that pastoral care has been consistently concerned with the caring ministry of religious communities, which is also the view of this article. Mills (1990:836) noted that historically and within the Christian community, pastoral care is in the cure-of-souls' tradition. Pastoral care, known as cura animarum [cure of souls], refers to the thorough care of people in their existential situations (Lartey 1997; Mills 1990).

Pastoral care and pastoral counselling are phrases that are sometimes used interchangeably in some parts of the world to refer to cura animarum even though the two are distinguishable (Magezi 2007:655-656). Whereas pastoral care refers to broad caring activities, pastoral counselling emphasises pastoral caring in the form of dialogue and communication to alleviate distress within the context of pastoral ministry. Benner (1992) explains the difference as follows:

Much as pastoral ministry is broader than pastoral care, so too is pastoral care broader than pastoral counselling. And to attempt to reduce all pastoral care to counselling is to fail to recognize both the breadth of pastoral care as well as the distinctive nature of counselling. (pp. 14-15)

Clinebell (1984:26) added that pastoral care is the broad, inclusive ministry of mutual healing and growth within a congregation and its community through its life cycle. Pastoral counselling, then, as an aspect of pastoral care, is the utilisation of a variety of healing (therapeutic) methods to help people handle their problems and crises in a more developmental way.

While the above distinction of pastoral care and counselling provides clarity to students of the discipline, a more useful process of developing a distinctive identity and greater expertise in the pastoral field is provided by Van Arkel (2000). He (Van Arkel 2000:143-160) mapped out the major 
trends and developments in the field of pastoral care and counselling as well as pastoral theology in the decade leading up to the year 2000. His mapping reflected published literature in the discipline. His review reflects on the major voices across the globe in the field of pastoral care. The greatest value of Van Arkel's work is in his concluding observations in which he insightfully discerned that pastoral care has reached a stage where it is necessary to identify four specifiable forms of pastoral work. These forms are mutual care, pastoral care, pastoral counselling and pastoral therapy (Van Arkel 2000:160). Mutual care is the first level of care and it is concerned with supporting and sustaining individuals by the community of believers. Pastoral care is the second level and it specialises in building up a community of believers through dialogical caring action. Pastoral counselling is the third level of care. It includes some kind of contract or agreement over a fixed time and place. It functions on entry level where other professions such as psychology counselling function. Pastoral therapy, which is the fourth level of care, uses longer term reconstructive therapeutic methods to heal deep, chronic problems. The distinction between pastoral counselling and pastoral therapy is that pastoral counselling is part of a larger ministerial function while pastoral therapy is specialised and uses therapeutic activities.

The foregoing distinctions are important in conceptualising pastoral care - particularly considering its 'shifts over the years' (Gerkin 1997:23-51; Heitink 1993:90-97). More importantly, it provides an embracing understanding of pastoral care both in the West, where it is significantly influenced by the findings in psychotherapy, and other places such as Africa where there is no distinction between pastoral outlook and practice - at least at the level of practice. Notwithstanding that the four level demarcations are fluid and dynamic in practice, they shed conceptual light. Ganzevoort writing about Practical Theology (2009) made remarks that are apt for pastoral care. He (Ganzevoort 2009:1-3) stated that the ways in which we move through the field of Practical Theology (and in our case, pastoral care) is too dynamic to be captured in a map. There are convergences in some areas and divergences in others. In this situation, Gerkin's advice (1997) is worth noting. He (Gerkin 1997:76) advised that in our time, pastoral caregivers should be more proficient interpreters. The pastoral caregivers should interpret the biblical and Christian language and its ways of seeing and evaluating the world of human beings and their affairs in order to shape their everyday life. Being an interpreter is a daily calling of pastoral care givers in the context of people's lives. This entails being on the frontlines of life with people and providing relevant pastoral care despite its mode, level and approach. This implies ministry at the frontlines in a fast changing world.

Notably, academic theological reflection on pastoral care in Africa has a short history compared to those in Europe and North America. Elsdörfer (2013), Gerkin (1997), Heitink (1993) and many other pastoral care scholars have carefully described the developments in pastoral care until the 21st century. This history excludes Africa for the obvious reason that there is little documented activity. This is very clear according to Gerkin (1997) and Heitink (1993). Pastoral care as a discipline is not yet significantly developed in many parts of Africa. By lack of development I mean the absence of a clear historically accounted path and a distinguishable school of thought. I contend that it is reasonable for one to conclude that the approaches employed on the continent are too diverse to allocate a framework. The situation has been compounded by little or no written history, or at least a description of developments in the discipline. However, this vacuum does not suggest that there are no recognisable voices in pastoral care scholarship. Many scholars engaging in cutting-edge scholarship in the discipline can be noted. For instance, African scholars' contributions to the publication by the Society for Intercultural Pastoral Care and Counselling based on Contributions in International Seminars (1988-2008) and Pastoral Care and Counselling Today Manuscript (1991) can be singled out as illustrations. These publications contain essays with a focus on African pastoral care issues authored by African Pastoral Care theologians. These include Masamba ma Mpolo, Kongo (Democratic Republic of Congo); Emmanuel Y. Lartey (based in the USA but originally Ghana); Charles K. Konadu (Ghana); Wilhelmina J. Kalu and Daisy N. Nwachuku (Nigeria); Daniel J. Louw, Julian Müller and Stephan de Beer (South Africa); Archiboldy Elifatio Lyimo and Derrick Lwekika (Tanzania); and Rose Zoé-Obianga (Cameroon).

The efforts of the above-mentioned African pastoral care theologians do not negate the reality of a young and developing scholarship. The African Association for Pastoral Studies and Counselling (AAPSC) was established in February 1985 after an ecumenical meeting held in Limuru, Kenya. It was initiated by Professor Jean Masamba ma Mpolo from the DRC (called Zaire that time) together with the World Council of Churches. At the same conference, a publication series on pastoral care and counselling in Africa, edited by Emmanuel Y. Lartey, Daisy Nwachuku, Kasonga wa Kasonga and Jean Masamba ma Mpolo, was founded. There have been subsequent AAPSC meetings, but the movement has lost momentum particularly in the last 10 years. This gap has weakened pastoral care reflection on the continent at a critical time. It is widely documented that Africa has the fastest growing church and yet a vacuum on pastoral care direction to systematise the ministry is clearly glaring. The observations made at the All Africa Conference of Churches more than half a century ago in the context of African church leadership still holds. Kohls (1998) recorded the 1964 All Africa Conference of Churches' observations that are particularly relevant in our current discussion of pastoral care. He (Kohls 1998: 107-110) noted that the church in Africa is in crisis, because it seems not to be equipping people to meet the ministerial needs on the continent. This situation has not changed much particularly in pastoral care reflection where the voices are fragmented.

Having been appointed as the Executive Treasure of the AAPSC in 2012, I have not encountered a single meeting that was formally arranged. The point here is not to suggest 
dysfunctionality, but as a proxy to indicate fragmentation. By fragmentation is meant no coherent theme, focus or guiding perspective. In such a situation where pastoral care scholars across the continent are fragmented, it is critical to reflect how pastoral care in Africa is being practiced. Stated differently: What is the hanging thread that defines pastoral care practice in Africa both from a theoretical reflection and at the frontline of ministry perspective? An attempt to respond to the above questions attracts criticism for a number of reasons. These include, firstly, the simplistic assumption of Africa as being homogenous whereas heterogeneity is the reality. Secondly, there is an apparent gulf between academic reflection and employed categories and images (e.g. in the writings of African theologians such as the late Bediako and others) and grassroots congregational ministry. Thirdly, there is diversity in pastoral care ministry practice across denominations, namely the traditional missionary started churches and the budding emerging African founded churches with a largely Charismatic and Pentecostal outlook. Fourthly, there is significant diversity in pastoral care approaches among practitioners from different theological persuasions (Ganzevoort 2009). Fifthly, there is sheer lack of a narrowed focus on the questions considered in pastoral care. Considering these challenges, it is important to state from the outset that this article's attempt to respond to the above posed questions is ambitious. However, its noble aims are to provide an overview and initiate a discussion of the current challenges in pastoral care in Africa. It furthermore aims to reveal some gaps worth pursuing by scholars in the discipline. In addition, it provides pointers for ministerial practice within the context of pastoral care diversity on the continent. In so doing, this article opens the lid on some perspectives on frontline ministries. In other words, it describes the way pastoral ministry among faith communities is being practiced.

\section{Pastoral care in Africa - An overview and a frontline approach}

Africa is heterogeneous with diverse groups of people. Despite this diversity, Masamba ma Mpolo (2013) rightly argued that there are clearly discernible elements that are common and can be found in different forms that homo africanus are organised. These are sanctity of life, relation between illness, misfortune and sin, spirits and ancestors in the life of the community, and life experienced as a whole.

Elsdörfer (2013), Louw (2008) and Masamba ma Mpolo (2013) explained the above homo africanus characteristics as follows: Sanctity of life means life comes from God (sometimes called Supreme Being) and finds its origin in him. Hence, life should be preserved by all means. The life of the individual is abundantly lived when it is shared and hidden in the life of his or her community. Illness and misfortune are associated with personal or group transgressions. The illness and death of an individual is explained in terms of the result of an offence against the ancestors, violation of social taboos, an attack by deities and evil spirits, or the result of witchcraft. Sin is associated with the breaking of prohibitions agreed by the community or inherited from the ancestors. The violation of morals leads to a severing of established relationships between God and his creatures and between the living and the departed ancestors - hence the illness or death. The place occupied by spirits and ancestors in African spirituality should also be noted. African cosmology is believed to contain a constellation of powers that constantly interact with human beings and influence - for good or for bad - the course of people's lives. God as the Creator of life and the Power that orders the universe is best revealed in and through ancestors, lesser deities and spirits. Life in Africa is viewed (w)holistically. To be whole is to be healthy and free from any sickness or life's challenges of any kind (e.g. healthy children, good marriage, stable job, being at peace with parents, etc.). The wholeness of life entails being free and being at peace both physically and spiritually. When life's challenges arise, people believe in the existence of diverse divinities, witches, wizards, the ancestral spirits and other innumerable spirit-beings that are capable of interfering in the affairs of human beings. Hence, one has to be in complete harmony with spiritual and physical forces.

The above elements broadly represent a common African framework regarding life and spirituality. For this reason, many African theologians and religion scholars refer to these elements in their work, for example Mbiti and Bediako. These scholars' discussions are located within Christian and African traditional religious experience. The implication of these elements is that Western religion at the end of the 19th century and during the entire 20th century, where pastoral care largely evolved to become the special occupation of psychotherapists (Elsdörfer 2013), is different to African pastoral care that has always been considered within the context of the churches' pastoral ministerial work. The efforts of African pastoral care scholars have centred on how to provide pastoral care that utilises Christian pastoral caring resources that incorporate African traditional experiences and potentials to ensure pastoral care that is contextually relevant and effective.

While the foregoing framework represents a generally predominant view, a notable situation across the African continent is the lack of a concise and defining approach or at least an organising centre for pastoral work refection and practice. Compared to the West where, for instance, psychotherapy could be identified, in Africa such a general organising centre is absent. Among the scholars who have contributed to pastoral care in Africa (African essays from 1988 to 2008 in Elsdörfer 2013), which include leading pastoral care scholars as indicated above and others, the themes are broad and diverse. For instance, Masamba ma Mpolo's essay he wrote in 1988 (Federschmidt, Temme \& Weiss 2013) describes spirituality and counselling for liberation focusing on the context and praxis of African pastoral activities and psychology. Lartey's 1991 and 1998 essays (Federschmidt et al. 2013) address the subject of healing in Africa. Nwachuku $(1991,2000)$ focus on creating communities through pastoral care and counselling in urban African life as well as the situation of women in Africa in the process 
of adjustment and change. The other themes considered include marital relationship, intercultural exchange, social change, violence in polygamous families, nurturing and building community, human dignity for youth and women, human dignity, spirituality and social-cultural analysis.

The broadness of pastoral care reflection in Africa, which renders this discussion superficial, is also evident in the book edited by Waruta and Kinoti (1994). The essays include the contributions of Philomena Mwaura, Douglas Waruta, Nasimiyu-Wasike, Jesse Mugambi, Laurenti Magesa, Constantine Mwikamba, Hannah Kinoti, Mary Getui, and Teresia Hinga. These scholars are largely from East Africa particularly from Kenya. The topics considered include ministerial formation, healing, counselling in African families, domestic violence against women, the plight of street children, growing old in Africa, and pastoral care of the clergy. These essays, just like the ones in the book edited by Federschmidt et al. (2013) shows a similar trend. The essays are diverse and deal with fragmented topics with no indepth discussion and reflection on the discipline - at least at theoretical level. Another significant theological work generated in Africa is Phiri's 'The Circle of Concerned African Women Theologians' (2005:34-41) commonly referred as the Circle. The Circle is a community of African women theologians who come together to reflect on what it means to them to be women of faith within their experiences of religion, culture, politics and social-economic structures in Africa (Macoba 2015; Phiri 2008:63). The Circle has generated a considerable amount of research regarding women of faith in Africa since its establishment in 1989.

Despite the significant work of the Circle, it has remained focused on women's liberation within theology and through theology nexus. The edited work by Federschmidt et al. (2013) largely contains essays of scholars predominantly from West Africa with a few voices from South Africa and East Africa. The work edited by Waruta and Kinoti (1994) carry essays of predominantly Kenyans. Gifford (2008:18) noted that East Africa, particularly Kenya, produces much more theology on the continent than many other African countries. The other comparable countries that produce significant theological work is Nigeria, Ghana and South Africa. Kenya's high volume of publications is made possible by two publishing companies: Paulines Publications and Acton Publishers. However, the literature produced is not widely distributed or known outside Africa. The quality of these publications is at a rather low academic level. Gifford (2008) rightly observed that these publications are produced:

as papers for meetings of the Ecumenical Symposium of East African Theologians (ESEAT), the Kenyan branch of the Ecumenical Association of Third World Theologians (EATWOT Kenya), and the local branch of the Circle of Concerned Women Theologians. (p. 18)

The papers are then collated and published. Bowers (2002, 2009) made similar observations as well that most of the publications are generated through meetings and conferences. These essays are usually written as short conference papers and they often lack depth and tend to only scratch the surface of issues and are generally uncritical to be deemed in-depth scholarly work. While the essays, contributing to pastoral care in East and West Africa, have tended to be generated from conferences, in South Africa much of pastoral care reflection is contained in peer-reviewed journals. These essays also tend to focus on broad issues just like in East and West Africa. Despite the above fragmented approach, Daniel Louw can be singled out as the most consistent and prolific practical and pastoral care scholar who has written extensively on the subject in South Africa. He has authored more than 10 books and more than 100 articles on various pastoral care issues with an African flavour. However, Louw's writings do not narrowly focus on African issues, but on global pastoral care theoretical and practical issues.

The apparent weak scholarly engagement on pastoral care can generally be traced back to the gap in the African theology movement. Bowers (2009:96-100) noted that African theological reflection, which I view as a discipline where robust pastoral care reflection in Africa should have budded from, has been substantially engaged in the discourse of cultural contextualisation and its theological implications. Different from theological reflections in Europe and North America, where they devote reflection to prevailing intellectual trends of their contexts and to the challenges that these trends represent for them, no such comparable critical attention exists within the African theological community where they engage intellectual trends of their context. This has resulted in intellectual issues such as pastoral care on the continent remaining uncharted in a serious manner. African theological reflection has remained preoccupied with establishing Africa's distinct identity against the West that is derived from independence agenda and ideology (Bowers 2009:102). Unfortunately, this has resulted in one-sided critical reflection where only the West is criticised while African traditional culture is romanticised. The participants in the African Theology Movement over the last five decades since the 1960s, who include influential voices such as Harry Sawyerr of Sierra Leone, Bolaji Idowu of Nigeria, John Mbiti of Kenya, Charles Nyamiti of Tanzania, John Pobee and Kwame Bediako of Ghana, Jesse Mugambi of Kenya and many others, have remained entangled in this cultural contextualisation debate. The implication for pastoral care is that critical issues that require in-depth and theoretical reflection have remained neither explored nor academically considered in a systematic manner. Gifford (2008:31-33) observed that this situation has caused a deficiency in African theological reflection. Bowers (2009:96-100), who has almost 40 years of theological education and church engagement in Africa, noted that there is a critical deficiency in African theological reflection that is increasingly being acknowledged by African theological scholars. The cultural contextualisation approach, as an influential movement, is clearly evident in pastoral care scholars' work such as Masamba ma Mpolo (2013) and Berinyuu (1988a).

Considering the broad and apparent lack of clear focus on African pastoral care, the following questions arise: How is pastoral care being practiced on the frontlines of ministry? How are 
pastoral theologians practicing ministry? These questions are critical in delimiting and focusing our discussion for the following reason: The pastoral care approaches, adopted by universities and other academic institutions such as seminaries, church leaders, and people (pastors) providing pastoral care at the forefront of ministry on a daily basis, differ. Lecturers at universities and academic institutions, which Bowers $(2002 ; 2009)$ called intellectuals, tend to focus on the cultural contextualisation debate where they look for categories that are relevant in African culture and should be incorporated into pastoral care, for example divination by Berinyuu (1988b). Church leaders' focus has been more interested in pastoral implications of the contextualisation discussion. On the one hand, Bowers (2002) stated that church leadership tends to frame its reflection more directly in terms of the pastoral and catechetical needs of the believing Christian community in Africa - especially as it is affected by traditional culture, for example with respect to rites of passage, polygamy, liturgical custom, divination, traditional healing or the role of ancestors. The people (pastors) providing pastoral care at the forefront of ministry on a daily basis tend to adopt multiplicity of approaches in practically administering pastoral care on the frontlines and space of real-life challenges where the rubber meets the $\mathrm{rod}$. The approaches tend to be informed by denominational background and practices. The focus of this article, particularly in the next section, is to consider people (pastors) providing pastoral care at the forefront of ministry, hence the working title Ministry at the frontlines. It is indeed valuable to consider pastoral care at the frontlines as Tiénou (1990) proposed. He (Tiénou 1990:74-76) rightly advised that the defining matrix of ministry in Africa, with its needs and expectations, its requirements and preoccupations, is the Christian community. This is particularly important in Africa, because, as Bowers (2009:94-100) observed, the intellectual preoccupations are at a tangent to what is practically happening in the lives of people on the ground. The African intellectual project does not reflect the needs and practicalities of church and pastoral care in life on the frontlines. Accordingly, it is worthwhile to follow Tiénou's advice (1990) as referred to above.

\section{Where forces meet: Pastoral care ministry on the frontline of people's lives}

There are two dimensions to pastoral care that are discernible in many parts of Africa. The first dimension relates to literature (publications) reflecting on pastoral care. The second relates to the actual practice of pastoral care ministry. Pastoral care reflections by churches that were started by missionaries generally focus on enculturation and correlation with African culture and theology. These churches include Roman Catholic and Protestant. The Protestant church includes conservative churches, and the ones with liberal and liberation orientation. The reflections are published in monographs, academic papers and journals. Consequently, literature from emerging churches with a strong Pentecostal and Charismatic background, largely rely on their church leaders' popular booklets. The booklets outline the leaders' views and opinions on various pastoral care issues at a popular level. While published literature can be identified, the actual pastoral care practice is much more difficult to describe. Pastoral caregivers practice it differently. Hence, pastoral care on the frontline requires a detailed consideration.

Pastoral ministry in many parts of Africa is practiced in at least seven discernible ways. These ways organically arise as responses to the context of people's pastoral needs. These approaches are distinct but integrated. They are often practiced eclectically. The application of these approaches is influenced, among other things, by church background, intensity of problems, position in family, distance of an individual from traditional extended family, level of education and age. These approaches have some resemblances with Landman's outline of Township Spiritualties and Counselling (2009), but it is much broader. The approaches derive from personal reflections on existing approaches:

- The first approach entails mixing African traditional practices and Christian pastoral care practices. When problems arise, the leaders, who are the prophets, perform rituals to exorcise and cast away the misfortune. They perform healing functions using substances such as water and oil. These prophets operate just like traditional diviners. In fact, there is very little difference between the way diviners and these prophets conduct their care to the people. These practices are prevalent in churches that are commonly called African Independent Churches (AIC) (Lartey 2013), white garment churches or Zionists in South Africa. Pastoral care is concerned with addressing the spiritual causes of misfortune and restored the person back to full health.

- The second approach is one that draws a dichotomy between Christian values and practical life. This approach is not verbalised, but rather acted upon by individuals in church communities. In this approach, people tend to hold and adhere to Christian values and virtues when there are no problems or threats to their lives. In times of problems, in addition to prayers and Bible reading, people, however, seek extra help from diviners and magicians. This approach is different to the first approach that falls within a Christian framework although the focus is on healing. In this approach, people revert to traditional healing practices. This is done in secret (usually at night) in order to maintain one's position in the church community. This is usually called syncretism. Pastoral caregivers therefore focus on guiding people to maintain faith in Jesus and trust him as capable in providing solutions to their situations. However, people under threat of spiritual forces find the message of pastoral caregivers unconvincing and unpractical in view of the spiritual challenges they experience. This usually occurs in missionary-started churches where the issues of spirituality in pastoral care were not significantly addressed.

- Thirdly is an approach that entails agonising and alienating Christianity. This entails church community members who remain trusting in the Christian caring 
message of Jesus without wavering. This stance sometimes results in ridicule and blame by extended family members and community. Pastoral care to these people entails supporting, sustaining and empowerment by the caregivers.

- The fourth approach focuses on formation of family and community coping with support structures. The extended family and community pressure often causes strain on the suffering people as indicated in the second and third approaches. To mitigate these challenges, church community leaders empower communities to establish alternative family support structures to provide an emotional net for people ostracised by relatives due to their stance in dealing with problems.

- The fifth approach is family group enrichment. Due to multifaceted challenges experienced by people, pastoral caregivers are establishing youth, family, male and female groups to discuss and explore solutions to the challenges of life. The focus of this approach is to address contemporary challenges experienced on the frontline of life.

- The sixth approach is exorcism and healing. Problems and any other life challenges are attributed to curses and evil attacks. Pastoral care entails conducting healing sessions and exorcism as reported in Lartey's 1988 essay (Federschmidt et al. 2013). The pastors pray over protective items such as water, oils, pieces of cloth and arm bands to ensure protection at all times. This approach is prevalent among new emerging Pentecostal and Charismatic churches.

- The seventh approach is position reversal. In times of severe problems, some individuals decide to abandon the Christian faith and its approaches to care and adopt a traditional African approach. Pastoral care to these people entails persuading them to return to the Christian faith and trust Jesus during their circumstances.

The above approaches present the general situations that pastoral caregivers encounter in pastoral ministry practice. The type of pastoral care provided is informed by the person's need and context. These pastoral needs are experienced on the various fronts and spaces of people's lives. It is important to note, however, that pastoral care in Africa is particularly a church ministry. Therefore, with little or no specialisation, pastoral care is considered as part of church pastoral work that is different to some areas in the West where ministries such as hospital ministry is considered a specialised ministry. There is limited specialised training in chaplaincy resulting in pastoral ministry assuming the role of chaplaincy.

The location of pastoral care as part of church ministry in Africa is in line with trends in pastoral care (Gerkin 1997; Heitink 1993; Van Arkel 2000). For Africa, however, this presents a simultaneous advantage and disadvantage. The location of pastoral care within the broader ministry context makes it a theological matter. There are many voices advocating an emphasis for pastoral care to maintain a strong theological character (Louw 2008:18-22; Mills 1990:836; Van Arkel 2000:149, 156). This way, pastoral care will remain rooted in its Christian and biblical foundation that was lost at the rise of psychology. However, the deep roots and entanglement with other theological disciplines presents it with a challenge of failing to address emerging and contemporary issues. It appears that pastoral care has largely remained preoccupied with the elements that Masamba ma Mpolo's 1988 essay (2013) rightly observed as homo africanus elements, namely sanctity of life; relation between illness, misfortune and sin; spirits and ancestors in the life of the community; and life experienced as a whole. These elements are evident in the issues raised above that pastoral care givers address through the indicated approaches. To a considerable extent the approaches seem preoccupied with healing, spirituality, spirits and ancestors, curses and spells, and community issues. These elements are important for pastoral care as they form the foundation for African people, but they are deficient in addressing emerging challenges in the modern and technologically advanced Africa. These challenges include the reality of Africa being sandwiched between modernity and African traditional patterns (Magezi 2010) - a phenomenon that is not adequately attended to. With pastoral care being part of an African theological discourse, it carries with it the weaknesses of the movement and thereby leaving a pastoral care vacuum. Bowers (2009:96-100) observed that the African Theology agenda and project has largely remained stuck in African identity issues and ignored the contemporary challenges. This has resulted in modern Africa remaining theologically an uncharted territory.

Gifford (2008:31-33) added that the above gap has caused many African scholars to fail in critically engaging with contemporary African challenges such as bad governance from a theological perspective. This gap challenges pastoral care to shift towards public theology that essentially is the emerging trend in pastoral care. There is growing interest in public theology as a significant trend in the discipline of pastoral care as theologians in pastoral care widen the lens of care to incorporate a critique of relevant cultural norms and practices (Koppel 2015). This entails shifting from care in faith communities to a concern about cultural disorder, injustice and oppression. Bonnie Miller-McLemore (2005: 102-103), who is one of the leading scholars in pastoral care, added that there is a clear shift that should be noted and heeded, namely the shift of pastoral care to public theology. This shift has not been taken place in Africa and it further impoverishes African pastoral reflection. Lartey (2013:10-20) noted that, even African led churches that provide pastoral care to Africans in the diaspora, exhibit backward African thinking and much less progressive African thinking.

Gifford (2008:31-33) advised that promoting 'traditional' African forms is worthwhile, but this should not be done uncritically. African traditional norms should not be promoted in a manner that is regressive by encouraging Africa to return to the past. If African Christianity and indeed pastoral care are to make a contribution to the world of Christianity, they should reconsider and improve their agenda in light of contemporary African challenges. 
The redesign should include refocusing on the Africa of the 21st century, focusing on Africa in a global context and to be critical of African approaches (Bowers 2009). From a pastoral care reflective perspective, there is a need to seriously engage with contemporary issues in a systematic manner. There is some engagement happening, but this needs to be substantially increased (see for instance Dames 2010; Muhindo 2010). However, what remains a huge gap is a substantial systematic consideration of pastoral care. It is important for pastoral care to respond to contextual challenges and critically reflect on its theory as well as its contribution to global care rather than be narrowly focused.

\section{Conclusion}

The article has highlighted how pastoral care took different forms in history to respond to people's needs in their context. These developments and evolvements have been clearly documented except in Africa. It pointed out that pastoral care in Africa has a short and unsystematically documented history. Scholarly discussions on pastoral care concerning the African continent have tended to be considered under African theological frameworks. However, with noted weaknesses in African theological discussion, pastoral care in Africa has remained fragmented with diverse and seemingly knee-jerk approaches in guiding individuals who provide pastoral care. In view of this, the article has provided a broad overview and initiated a starting point for a discussion on the current challenges in pastoral care in Africa. It has also flagged some gaps worth pursuing by scholars in the discipline. Importantly also, the article has shed light on some approaches employed by pastoral care practitioners in pastoral ministry practice. In so doing, it is hoped that this article has opened a lid on some perspectives adopted in ministry work on the frontlines where people provide pastoral care to people in their communities - particularly church communities.

\section{Acknowledgements Competing interests}

The author declares that he has no financial or personal relationships which may have inappropriately influenced him in writing this article.

\section{References}

Benner, D.G., 1992, Strategic pastoral counselling: A short-term structured model, Baker, Grand Rapids, MI.

Berinyuu, A.A., 1988a, 'The encounter of Western Christianity and civilization, and Islam on Ghanaian culture: Implications for the Ministry of Pastoral Care and Counselling', Africa Theological Journal 17, 140-149.

Berinyuu, A.A., 1988b, 'Transcultural approach to pastoral care of the sick in Ghana' Africa Theological Journal 16, 53-66.

Bowers, P., 2002, 'African theology: Its history, dynamics, scope and future', Africa Journal of Evangelical Theology, 21, 109-125.

Bowers, P., 2009, 'Christian intellectual responsibilities in modern Africa', Africa Journal of Evangelical Theology 28, 91-114.

Clinebell, H., 1984, Basic types of pastoral care counselling: Resources for the Ministry of Healing and Growth, Abingdon, Nashville, TN.
Dames, G.E., 2010, 'The dilemma of traditional and 21st-century pastoral ministry: Ministering to families and communities faced with socio-economic pathologies', HTS Teologiese Studies/Theological Studies 66(2), Art. \#817, 1-7. http://dx.doi. HTS Teologiese Studies/Theolo
org/10.4102/hts.v66i2.817

Elsdörfer, U., 2013, 'Africa in pastoral care and counselling', in U. Elsdörfer (ed.), Inhalt, pp. 157-167, LIT Verlag, Münster, Berlin.

Federschmidt, K., Temme, K. \& Weiss, H. (eds.), 2013, Voices from Africa on pastora care: Contributions in international seminars 1988-2008, Magazine of the Society for Intercultural Pastoral Care and Counselling (SIPCC), viewed 10 March 2016, from www1.ekir.de/sipcc/downloads/IPCC-020-txt.pdf

Ganzevoort, R.R., 2009, 'Forks in the road when tracing the sacred. Practical theology as hermeneutics of lived religion', paper presented at the International Academy of Practical Theology, Chicago, 3 August.

Gerkin, C.V., 1997, An introduction to pastoral care, Abingdon Press, Nashville, TN.

Gifford, P., 2008, 'Africa's inculturation theology: Observations of an outsider', Hekima Review 38, 18-34.

Heitink, G., 1993, Practical theology. History, theory action domains: Manual for practical theology, transl. R. Bruinsma, WB Eerdmans Publishing Company, Grand Rapids, MI.

Kohls, P., 1998, 'A look at church leadership in Africa', Africa Journal of Evangelical Theology 17, 107-126.

Koppel, M.S., 2015, 'Practicing public pastoral theologies in contexts of difference', Journal of Pastoral Theology 25(3), 151-152. http://dx.doi.org/10.1080/1064986 7.2015.1123923

Landman, C., 2009, Township spiritualties and counselling, Unisa Press, Pretoria.

Lartey, E.Y.A., 1997, In living colour: An inter cultural approach to pastoral care and counseling, Cassell, London.

Lartey, E.Y.A., 2013, Postcolonializing God: An African practical theology, SCM Press, London.

Louw, D., 2008, Cura vitae: Illness and the healing of life in pastoral care and counselling, Lux Verbi, Cape Town.

Macoba, V., 2015, 'Celebrating the legacy of the Circle of Concerned African Women Theologians', viewed 17 June 2016, from http://www.unisa.ac.za/chs/news/ 2015/11/celebrating-the-legacy-of-the-circle-of-concerned-african-womentheologians

Magezi, V., 2007, 'Pastoral counselling: Towards a diagnostic and interpretational approach in Africa', In die Skriflig 41(4), 655-672. http://dx.doi.org/10.4102/ids. v41i4.325

Magezi, V., 2010, Pastoral care in tension between tradition and modernity: Pastoral ministry and biblical response to challenges of fear of death, fear of spirits and hospitality in Africa, Lambert Academic Publishing, Saarbrücken, Germany.

Masamba ma Mpolo, 2013, 'Spirituality and counselling for liberation: The context and praxis of African pastoral activities and psychology', in K. Federschmidt, and praxis of African pastoral activities and psychology', in K. Federschmidt, K. Temme \& H. Weiss (eds.), Voices from Africa on pastoral care: Contributions in international seminars 1988-2008, pp. 7-18, Magazine of the Society for Intercultural Pastoral Care and Counselling (SIPCC), viewed 10 March 2016, from www1.ekir.de/sipcc/downloads/IPCC-020-txt.pdf

Miller-McLemore, B.J., 2005, 'Pastoral theology and public theology', in E.L. Graham \& A. Rowlands (eds.), Pathways to the public square: Practical theology in an age of pluralism, pp. 95-106, Lit Verlag, Münster, Berlin.

Mills, L.O., 1990, 'Pastoral care - History, traditions, and definitions', in R.J. Hunter (ed.), Dictionary of pastoral care and counselling, pp. 836-842, Abington Press, Nashville, TN.

Muhindo, V., 2010, 'The pastoral challenges of urbanization in Uganda: Response of the Church', viewed 5 April 2016, from http://www.sedosmission.org/web/en/ mission-articles/doc view/1811-the-pastoral-challenges-of-urbanization-inuganda-response-of-the-church

Nwachuku, D.N., 1991, 'The situation of women in Africa in the process of adjustment and change', in K. Federschmidt, K. Temme \& H. Weiss (eds.), Voices from Africa on pastoral care: Contributions in international seminars 1988-2008, Magazine of the Society for Intercultural Pastoral Care and Counselling (SIPCC), pp. 35-52, viewed 10 March 2016, from www1.ekir.de/sipcc/downloads/IPCC-020-txt.pdf

Nwachuku, D.N., 2000, 'Creating communities through pastoral care and counselling in the fragmentations of urban African life', in K. Federschmidt, K. Temme \& $\mathrm{H}$. Weiss (eds.), Voices from Africa on pastoral care: Contributions in international seminars 1988-2008, pp. 97-106, Magazine of the Society for Intercultural Pastoral Care and Counselling (SIPCC), viewed 10 March 2016, from www1.ekir. de/sipcc/downloads/IPCC-020-txt.pdf

Patton, J.H, 2013, 'International Council on Pastoral Care and Counselling', in U. Elsdörfer (ed.), Inhalt, pp. 99-103, LIT Verlag, Münster, Berlin.

Phiri, I.A., 2005, 'The Circle of Concerned African Women Theologians', The Ecumenical Review 57(1), 34-41. http://dx.doi.org/10.1111/j.1758-6623.2005.tb00216.x

Phiri, I.A., 2008, 'Major challenges for African women theologians in theological education (1989-2008)', Studia Historiae Ecclesiasticae 34(2), 63-81.

Tiénou, T., 1990, 'Indigenous African Christian theologies: The uphill road', International Bulletin of Missionary Research, April, 73-76.

Van Arkel, J.d.J., 2000, 'Recent movements in pastoral theology', Religion and Theology 7, 142-167. http://dx.doi.org/10.1163/157430100X00351

Waruta, D.W. \& Kinoti, H.W. (eds.), 1994, Pastoral care in African Christianity: Challenging essays in pastoral theology, Action Publishers, Nairobi. 